\title{
ÉSZAK-ALFÖLDI AKÁC, NEMESNYÁR ÉS KOCSÁNYOS TÖLGY ERDŐÁLLOMÁNYOK HATÁSA A TALAJVIIZRE ÉS IONFORGALOMRA
}

\author{
Szabó András ${ }^{1}$, Gribovszki Zoltán ${ }^{2}$, Bolla Bence ${ }^{3}$, Balog Kitti ${ }^{4}$, Csáfordi Péter $^{5}$ és Tóth Tibor ${ }^{4}$ \\ ${ }^{1}$ NAIK Erdészeti Tudományos Intézet, Ökológiai és Erdőmüvelési Osztály \\ ${ }^{2}$ Sorponi Egyetem, Geomatikai, Erdőfeltárási és Vízgazdálkodási Intézet \\ ${ }^{3}$ NAIK Öntözési és Vizgazdálkodási Kutatóintézet \\ ${ }^{4}$ MTA ATK, Talajtani és Agrokémiai Intézet \\ ${ }^{5}$ Pest Megyei Kormányhivatal Környezetvédelmi és Természetvédelmi Főosztály
}

\begin{abstract}
Kivonat
Az alföldi erdőállományok hidrológiai folyamatokban betöltött szerepe a mai napig vita tárgya. Ennek egyik oka a folyamatokban szerepet játszó, nagy számú és variabilitású lokális tényező.

Egy 2012-óta zajló kutatássorozat összesen 108 mintaponton, egyszeri mintavételezés, állományfelmérés és talajvíz monitoring segítségével vizsgálja az erdőállományok talajvízszintre és a talaj ionforgalomára gyakorolt hatását.

Az eredmények általánosságban az állományok alatti talajvíz depresszió és az ionakkumuláció tekintetében is megerösítették a hipotézisben megfogalmazottakat. Ugyanakkor rávilágitottak arra is, hogy fafajok eltérő vízfelvételi stratégiája, illetve az egyéb lokális tényezők (topográfiai elhelyezkedés, talajtextúra) alapvetően befolyásolják a lezajló folyamatokat. A fentiekböl következik, hogy az erdöállományok talajvizre gyakorolt hatását, nem helyes kizárólag azok nagyobb mértékü párologtatása alapján megbecsülni, ahhoz szükséges a tényezők komplex megközelitése. Ebben lehet lehet hasznos eszköz a talajvíz monitoringja és a talajban történő iontranszport vizsgálata is.
\end{abstract}

Kulcsszavak: erdőállományok vízháztartása, talajvizszint depresszió, ionakkumuláció.

\section{EFFECT OF ROBINIA PSEUDOACACIA, POPULUS X. EURAMERICANA, AND QUERCUS ROBUR PLANTATIONS ON GROUNDWATER AND IONTRANSPORT AT THE NORTHERN HUNGARIAN PLAIN}

\begin{abstract}
The role of forests in hydrological processes on the Great Hungarian Plain is still a subject of debate. Among the causes there are numerous and highly variable local factors taking part in the processes.

This research investigated the impact of forests on groundwater levels and ion transport of the soil since 2012 on 108 study sites, using one-time soil sampling, forest stand measurements and groundwater monitoring.

Results in general supported the assumptions of the hypothesis in correlation with groundwater depression and ionaccumulation under forest stands. Meanwhile the same results highlighted that different water-uptake strategies of different tree species and other local factors (topography, soil texture) highly influenced the processes.

Consequently it is not correct to evaluate the impact of forest stands exclusively by their increased evapotranspiration. For this purpose complex approach is necessary in which groundwater monitoring and investigation of ion transport also could be used as useful instruments.
\end{abstract}

Keywords: hydrological regime of forests, watertable depression, ionaccumulation. 


\section{BEVEZETÉS}

Az erdőállományok az Alföld vízgazdálkodásában betöltött szerepével kapcsolatos kutatások immár több mint nyolcvan éve kezdődtek el hazánkban (ljjász 1938) és annak ellenére, hogy az azóta eltelt évtizedekben számos kiváló kutató foglalkozott a kérdéskörrel a mai napig szakmai viták jellemzik a területet, különösen a megfigyelhetö talajvízszint csökkenés és az erdőállományok kapcsolatára vonatkozóan (Járó 1981, Szodfridt 1993, Major 2002, Göbölös 2002). Ennek egyik oka a folyamatokban szerepet játszó számos, igen változékony, és esetenként igen nehezen megfigyelhető tényező (pl.: egy erdőállomány gyökérmélysége, a talajfelszín alatti horizontális talajvízáramlás).

2012-2015 közt az MTA ATK Talajtani és Agrokémiai Kutatóintézet, a NAIK Erdészeti Tudományos Intézet, a Nyugat-Magyarországi Egyetem, és a Magyar Állami Földtani Intézet részvételével lezajlott OTKA pályázat („Sekély talajvizű területeken telepített ültetvények által a talajban és altalajban okozott sófelhalmozódás statisztikai és hidrológiai modellezése") a telepitett erdőállományok és a talaj sóforgalma közti összefüggéseket vizsgálta. Annak köszönhetően, hogy a kutatómunka számos tényezőre kiterjedt, illetve, hogy a NAIK Erdészeti Tudományos Intézet a pályázat lejárta után átvette és tovább üzemelteti a kiépített monitoring hálózatot, számos a témakörrel kapcsolatos eredmény született (Balog et al 2014, Gribovszki et al 2014, Tóth et al 2014, Móricz et al 2016, Csáfordi et al 2017, Szabó et al 2018). Jelen kutatómunka célja a felállított alaphipotézis vizsgálatára korlátozódik, a különböző befolyásoló tényezők figyelembevétele mellett, építve a korábban elért eredményekre.

Az alaphipotézis feltételezi, hogy a telepített erdőállományok (lágyszárú vegetációéhoz viszonyított) nagyobb mértékủ vízfelvétele megváltoztatja az adott terület vízforgalmát, aminek következtében az erdők alatt talajvízszint depresszió alakul ki. Ez a folyamat szükségszerủen hatással van a talajvízben oldott sók mozgására: A növények szelektív ionfelvétele miatt a fel nem vett ionok feldúsulnak és a gyökérzethez kapcsolódóan sóakkumulációs réteget képeznek. Fontos megemlíteni, hogy ez a réteg nem feltétlenül a gyökérzet mélységében alakul ki, és azt is, hogy ez a réteg - sekélyebben - a lágyszárú vegetáció alatt is jelentkezhet.

\section{VIZSGÁLATI ANYAG ÉS MÓDSZER}

A bevezetőben említett OTKA pályázat célkitüzéseihez igazodva a területek kijelölése egy előzetesen meghatározott kategóriamátrix segítségével történt. Az ebben szereplő paraméterek és kategóriák a következők voltak:

- a vizsgált fafajok (Quercus robur L., Robinia Pseudoacacia L., Populus x. euramericana)

- az ültetvény kora (10-20, 30-40, 50-60 év)

- a talajszelvény textúratípusa (agyag, vályog, homok) 
- a megütött talajvíz mélysége (1-2, 2-4, 4-8 m)

- a talajvíz sótartalma (1-2, 2-5, 5-10 g/l)

Mindegyik mintaterület kettő vagy több mintavételi pontból áll: egy lágyszárú vegetációval (szántó, rét) borított kontroll pontból, továbbá a közeli erdőállomány(ok) mérési pontja(i)ból. A mintavételezés minden évben augusztus és október között történt. A szegélyhatás elkerülése érdekében, a furatok az erdőállományok és a kontrollvegetáció határától legalább 5050 m-re kerültek kijelölésre. Ezek mélysége minden esetben a megütött talajvízszint $+1 \mathrm{~m}$, illetve maximálisan $11 \mathrm{~m}$. Az erdei mintaterületeken a fák magassága és a mellmagassági $(130 \mathrm{~cm})$ átmérője alapján fatömeg becslés készült.

A talaj felső $1 \mathrm{~m}$-es rétegében $20 \mathrm{~cm}$-enként, ez alatt $50 \mathrm{~cm}$-enként történt talajmintavétel. Az így vett talajmintákból laboratóriumi vizsgálatok során részletes talajszemcse összetétel, hy1 (Sík-féle higroszkóposság) pH, vezetőképesség ( $E C)$, mésztartalom $\left(\mathrm{CaCO}_{3}\right)$, a talajvízmintákból pedig az $\mathrm{EC}$, a pH, a nátrium és kloridion aktivitás ( $\mathrm{pNa}, \mathrm{pCl})$ meghatározása történt meg.

A leírtak alapján 78 mintavételi ponton (53 erdőállomány, 25 kontroll) egyszeri mintavétel történt, míg 29 monitoring ponton (17 erdőállomány és 12 kontroll) nyomásmérő szenzorok kerültek telepítésre melyek 15 percenként regisztrálták a talajvízszint változásait. Az így kialakított mintaterületek helyszíneit az 1. ábra mutatja be.

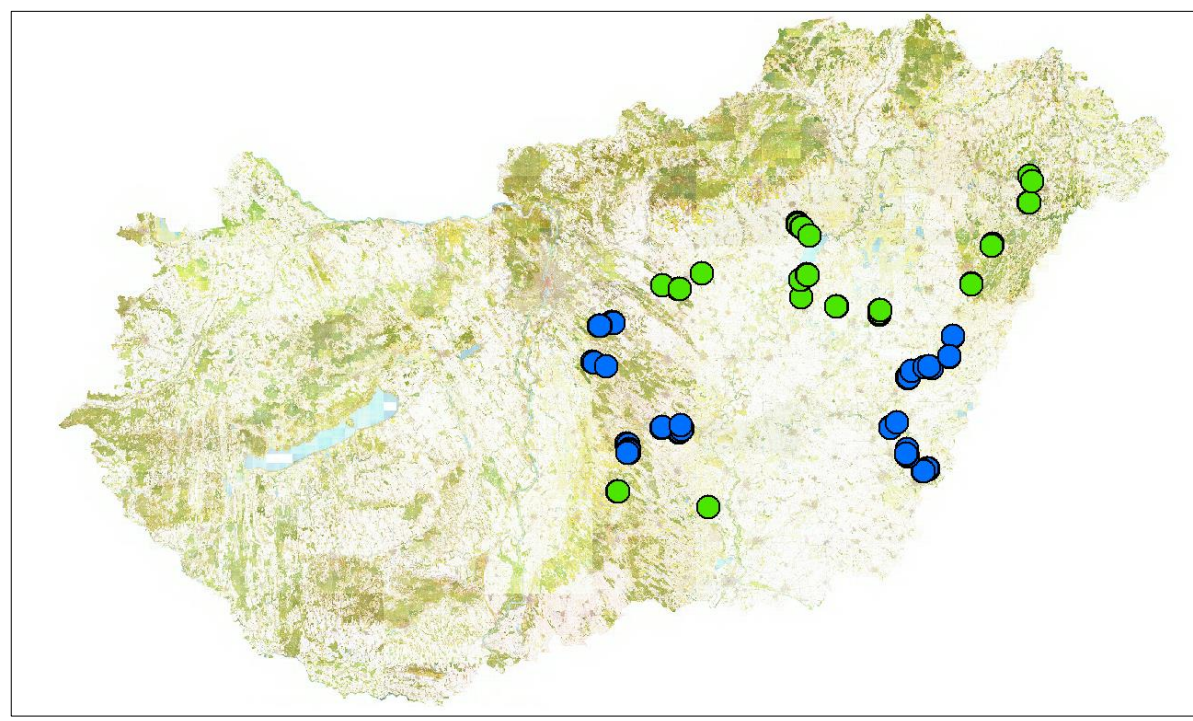

1. ábra: A mintavételi területek elhelyezkedése.

(Zöld helyjelző: monitoring pontok, Kék helyjelző: egyszeri mintavétel pontjai)

Figure 1: Locations of the study sites.

(Green marker: monitoring sites; Blue marker: sites of one time sampling)

Az ionakkumulációval kapcsolatos vizsgálatok kapcsán a mintaterületek további szürésen estek át: Feltétel volt, hogy a kontroll és erdőpontok távolsága kisebb legyen, mint 
500 m, a kiválasztott mintaterületek lefutási görbéin egyértelműen meg lehessen állapítani a $\mathrm{CaCO}_{3}$ és $\mathrm{Cl}^{-}$csúcsok mélységét, továbbá az, hogy ezen csúcsok egymástól való távolsága $50 \mathrm{~cm}$-nél kisebb legyen. Ezekkel a feltételekkel a geológiai rétegződésből adódó eltéréseket igyekeztünk kizárni.

\section{EREDMÉNYEK ÉS MEGVITATÁSUK}

\section{Talajvízszinttel kapcsolatos eredmények}

Az eredmények általánosságban a talajvíz depresszió (2. ábra) tekintetében megerősítik a hipotézisben vázoltakat, ugyanakkor jelentős eltéréseket tapasztalhatunk az egyes fafajok között.

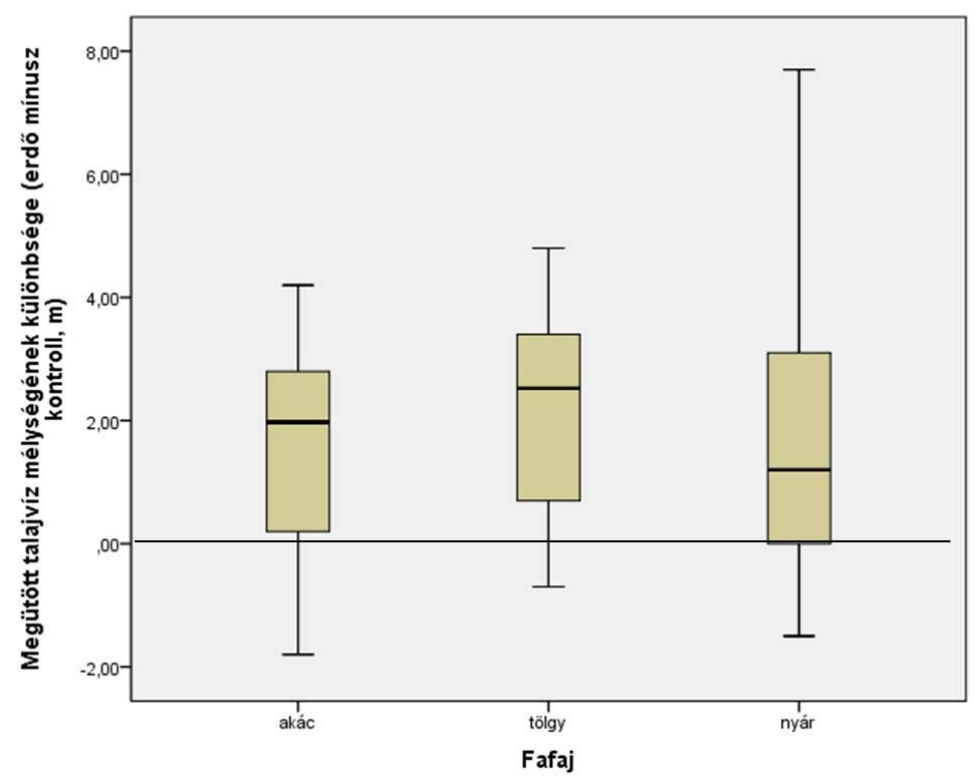

2. ábra: Az erdoaállományok és a kontrollterületek alatt megütött talajvízszintek különbsége fafajonként, kiugró értékek nélkül (akác $n=22$, tölgy $n=18$, nyár $n=26$, összesen 66 esetben történt sikeres vízmintavétel).

A pozitív értékek az erdő alatti talajvíz depressziót jelzik. (A maximálisan mért érték a fúrás technikai feltételei miatt nem lehetett nagyobb, mint 10,5 m.)

Figure 2: Differences in groundwater levels between forest stands and control points by tree species. Extreme values were excluded (black locust $n=22$, oak $n=18$, poplar $n=26$, number of successful water sampling: 66). Positive values show groundwater level depression under forests. (The maximum depth was $10,5 \mathrm{~m}$, due to technical restrictions in borehole drilling.)

Az adatok azt mutatják, hogy az erdőállományok többsége alatt a megütött talajvízszintek a kontroll pontokhoz viszonyítva mélyebben helyezkedtek el $(84,8 \%, n=66)$. Ugyanakkor 
fontos kiemelni, hogy a nyár állományok esetében a legmagasabb azon mintaterületek száma $(19,2 \%, n=26)$, ahol ez a hatás nem kimutatható, továbbá a számszerüsíthetö relatív talajvízszint csökkentő hatás is a nyár alatt a legalacsonyabb, miközben a vizsgált fafajok közül ezen fafaj vízigénye a legmagasabb (Járó 1981).

Ugyanezen területekre vonatozó, részletesebb időbeli felbontású talajvíz monitoring adatok alapján Csáfordi et al (2017) vizsgálták az egyes állományok talajvízből történő vízfelvételét. A vizsgált területek alatti napi talajvízszintingadozást felhasználva, a White-módszer (White 1932) továbbfejlesztett változatának (Gribovszki 2008) segítségével, a nyáras erdöállományok nagyobb mértékü talajvízből történő vízfelvételét mutatták ki (1. táblázat).

1. táblázat: Az egyes vegetációs típusok és fafajok alatti korrigált napi vízingadozás mértéke (amely arányos a talajvízfelvétellel) a mintaterületek alatt (a leüríthető gravitációs pórustérrel beszorzott értékek).

(Csáfordi et al 2017 alapján)

Table 1: Corrected values of daily groundwater level fluctuation (proportional to groundwater consumption) under study sites. (Values were multiplied by specific yield.) (Based on Csáfordi et al 2017)

\begin{tabular}{|l|c|}
\hline Növényborítás & Átlagos napi vízingadozás (mm/nap) \\
\hline Lágyszárú kontroll & $0,8+/-1,8 \mathrm{~mm}$ \\
\hline Akác & $0,6+/-0,6 \mathrm{~mm}$ \\
\hline Tölgy & $1,7+/-4,0 \mathrm{~mm}$ \\
\hline Nyár & $2,2+/-2,5 \mathrm{~mm}$ \\
\hline
\end{tabular}

A látszólagos ellentmondásra magyarázatot az egyéb topgráfiai és hidrológiai tényezők adnak. A nyár állományokat jellemzően olyan mélyebben fekvő, jobb vízellátottságú területekre telepítették, ahol az említett nagyobb vízigény nagy biztonsággal fedezhető. Ezzel ellentétben az akácot, mely vízigényét a lehulló csapadékból is képes fedezni, gyakrabban magasabb térszíneken találhatjuk. Ezt mutatja a talajvízszint felszíntől számított átlagos mélységének eltérése is a nyár $(5,53 \mathrm{~m}+/-2,22 \mathrm{~m})$, a tölgy $(5,1 \mathrm{~m}+/-3 \mathrm{~m})$, illetve az akác $(6,53 \mathrm{~m}+/-1,98 \mathrm{~m})$ állományok esetében. Az említett mélyebben fekvő területek hidrológiai szempontból gyorsabb visszatöltődéssel jellemezhetők, ez a folyamat pedig elfedheti az erdőállomány vízfelvételében jelentkező különbségeket.

Ezen eredmények alapján azt az igen fontos következtetést vonhatjuk le, hogy az egyes fafajok talajvízszintre gyakorolt hatására nem következtethetünk csupán annak vízigényéből, a talajvíz mozgására egyéb - sok esetben lokális - tényezők is igen nagy hatással vannak.

Szintén a lokális tényezők fontosságára példa a napi talajvízingadozás jászsági mintaterületeken, 2012. júliusában megfigyelhető viselkedése: A Jászfelsőszentgyörgyön és Jászjákóhalmán található mintaterületek egymástól 19 km-re találhatóak, ezért az időjárási viszonyok azonosnak tekinthetők a két területen. Az előbbi esetében az erdőállományokon (tölgy, nemesnyár) túl a kontrollterület alatt is megfigyelhető volt a napi talajvíz-ingadozás jelensége. Míg a jászjákóhalmai mintaterületen ez se az erdő, se a kontrollterület alatt nem 
volt megfigyelhető (3. ábra). A fafajok fent említett eltérő vizfelvételi stratégiáján túl, ezt a két terület talajtani és hidrológiai különbözőségei is magyarázzák.

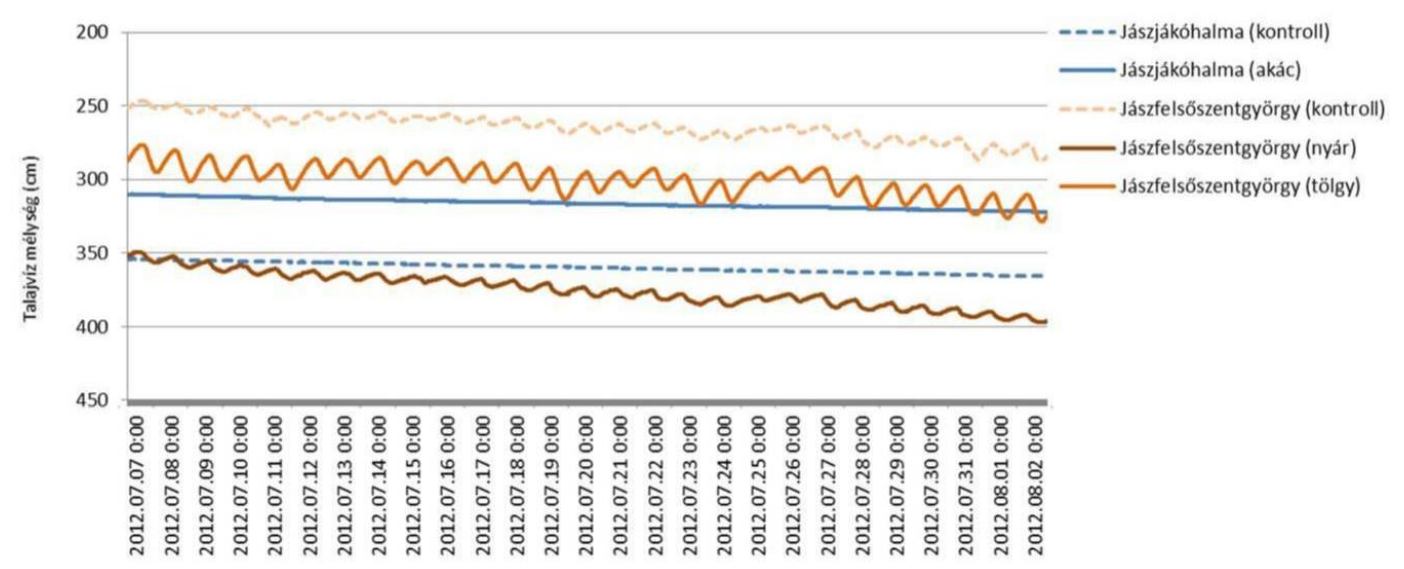

3. ábra: Talajvízszint napi ingadozása a jászsági mintaterületeken 2012. július 7. és augusztus 12. közt.

Figure 3: Daily fluctuation of groundwater levels at monitoring sites of the Jászság region between 7.07.2012 and 12.08.2012.

Jászfelsőszentgyörgyön a talajvíz sekélyebben helyezkedik el, a finomabb (homokos vályog, vályog, agyagos vályog) talajtextúrájú fluktuációs zóna által biztosított kapilláris vízemelés felső határa pedig az 1-1,5 métert is elérheti. Emiatt a talajvizet a kontrollterületen található lágyszárú növényzet is képes hasznositani. A jászjákóhalmai mintaterület talaját a homok és durva homok textúratípus jellemzi, melyben a kapilláris vízemelés jelentősége elhanyagolható (maximálisan 0,1-0,2 m). Ennek következtében a 3-3,5 m-es mélységben található talajvíz az akác számára sem hasznosítható.

\section{lonakkumulációval kapcsolatos eredmények}

Az erdőállományok alatti, kontrollterületekhez viszonyított, ionfelhalmozódás mélységi lefutását a 4. ábra mutatja be.

Látható, hogy a lefutási görbék mindhárom fafaj esetében hasonló mintázatot mutatnak, azaz a sekély talajrétegekben (nagyjából 1-1,25 m-ig) a kontroll, ennél mélyebben pedig az erdőállományok alatt mérhető nagyobb sótartalom. Mivel ez utóbbi mértéke meghaladja a kontrollterületek alatti felhalmozódás nagyságát, a teljes szelvény átlagában nézve az erdöállományok alatt mérhető nagyobb sófelhalmozódás.

Ez a fajta megoszlás általánosságban szintén alátámasztja az alaphipotézisben megfogalmazottokat. Ugyanakkor ebben az esetben is jelentős különbségek fedezhetök fel az egyes fafajok közt: Míg a nyár és a tölgy állományok alatt mérhető sófelhalmozódás hasonló mértékü, addig az akác alatti annak mértéke jóval kisebb. Ez egybevág az alaphipotézis 
azon feltételezésével, miszerint sófelhalmozódás az erdőállományok vízfelvételének következménye, tehát a kisebb vízfelvétellel jellemezhető akác kisebb mértékủ sófelhalmozódást generál.

További, az erdészeti gyakorlat számára is fontos eredmény, hogy a mért sómaximumok minden esetben jelentősen (általában egy nagyságrenddel) alacsonyabbak voltak, mint az adott fafaj sótürő képessége. Azaz ez a fajta sóakkumuláció nem jelent veszélyt az erdőállományokra nézve, ellentétben egyes külföldi kutatások eredményeivel (Jobbágy \& Jackson 2007).

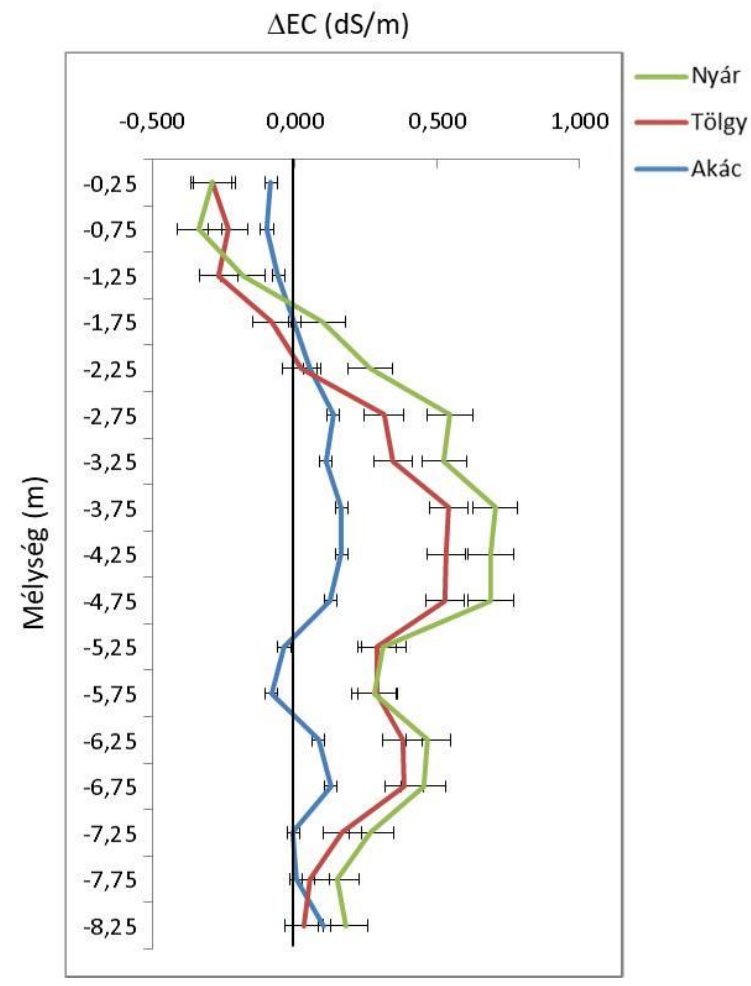

4. ábra: Az erd̋állományok és a kontrollterületek alatti elektromos vezetöképesség különbségek fafajok szerint (erdő mínusz kontrol pont). A pozitiv értékek EC felhalmozódást jeleznek

(akác $n=20$, tölgy $n=15$ nyár, $n=26$ ).

Figure 4: Differences of the electrical conductivity between forest stands and control points by tree species (values at forested points minus values at control points). Positive values show ionaccumulation under forests (black locust $n=20$, oak $n=15$, poplar $n=26$ ).

További összefüggéseket fedezhetünk fel, amennyiben az összsótartalom helyett a $\mathrm{CaCO}_{3}$ és a $\mathrm{Cl}^{-}$akkumulációját vizsgáljuk a mintaterületeken. Az ezzel kapcsolatos eredményeket a 5. ábra mutatja be. 
Feltűnő, hogy a két fafaj és a két vizsgált ion is eltérő viselkedést mutat: Akác állományok alatt felhalmozódás mértéke kisebb, ha egyáltalán kimutatható. A vizsgált ionok szempontjából ugyanez érvényes a $\mathrm{CaCO}_{3}$-ra összevetve azt a kloridionnal.

Utóbbi különbség könnyen magyarázható, amennyiben figyelembe vesszük ezen ionok mobilitását talajban. Míg a kloridion nem hajlamos komplexek képzésére a talajban, ezért a talajvízzel együtt rendkívül könnyen mozog, ellentétben a Ca²+ ionokkal. Ezért az erdöállományok vízfelvétele miatti talajvíz mozgás nagyobb mértékủ akkumulációt képes generálni a kloridion esetében.

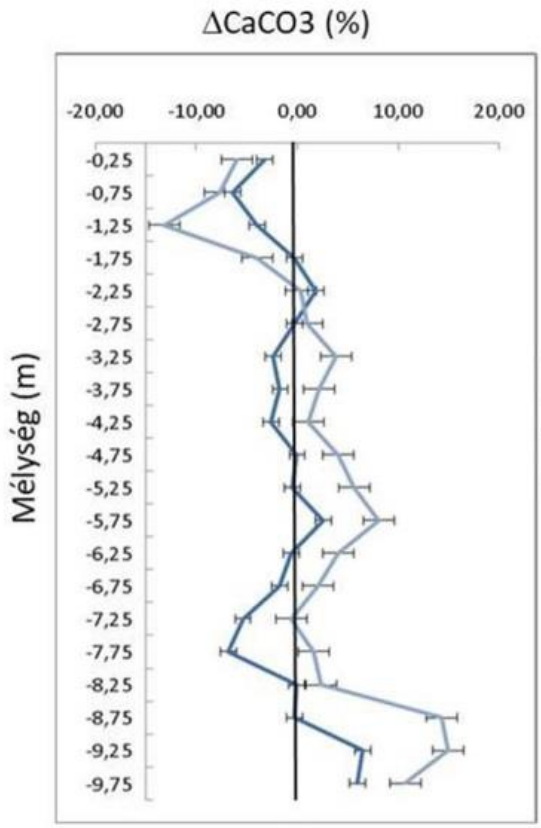

(a)

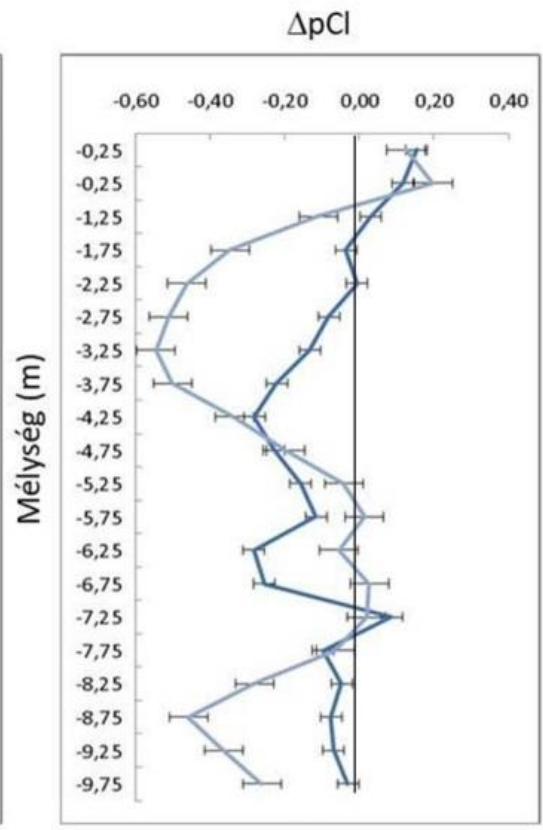

(b)

5. ábra: Átlagos $\mathrm{CaCO}_{3}$ (a) és $\mathrm{Cr}$ (b) felhalmozódás, görbék a vizsgált akác és nyár állományok alatt (erdö mínusz kontrol pont). A pozitív értékek $\mathrm{CaCO}_{3}$ felhalmozódást (a), míg a negatív értékek $\mathrm{Cl}$ - felhalmozódást

(b) jeleznek a kontrollpontokhoz képest. (akác $n=11$, nyár $n=11$ ) (Szabó et al 2018 alapján)

Figure 5: Average $\mathrm{CaCO}_{3}(a)$ and $\mathrm{Cr}$ (b) accumulation curves under investigated black locust and poplar stands. (Values at forested points minus values at control points.) Positive values show $\mathrm{CaCO}_{3}$ accumulation

(a), negative values show $\mathrm{Cl}$ accumulation (b) under forests. ( $n=11$ black locust, poplar $n=11)$

(Based on Szabó et al 2018.)

Az akkumulációs görbékben látható fafajok közti különbség nem csak az akác alacsonyabb vízigényéből fakad, hanem a két faj eltérő vízfelvételi stratégiáajából is: A szakirodalmi adatok (Járó 1981, Keresztesi 1968, Gőbölös 2002) szerint, az akác főként a talajnedvességet, illetve a kapilláris vízemeléssel a talajvízböl a gyökérzetéhez eljutó nedvességet használja fel vízigényének fedezésére. Ezzel ellentétben a nyár elsősorban a talajvízből történő közvetlen vízfelvételre törekszik. Így míg az akác gyökérzónájában a benedvesedés és 
kiszáradás váltja egymást, a nyár esetében folyamatos és egyirányú talajvízmozgás a jellemző. Ez utóbbi értelemszerűen nagyobb mértékủ akkumulációt generál azonos idő alatt.

További kapcsolatot találtunk az ionakkumuláció és más biotikus tényezők közt. Szignifikáns összefüggés tapasztalható az erdőállományok kora $\left(R^{2}=0,466, p<0,05, n=31\right), a$ dendromassza nagysága $\left(R^{2}=0,480, p<0,01, n=31\right)$, illetve a felhalmozódás mértéke közt. Ugyanakkor az eredmények az utóbbi esetben differenciáltak. Más-más erősséggel ugyan, de a nyár és a tölgy állományok tekintetében is szignifikáns a szóban forgó kapcsolat, miközben az akácnál ez nem áll fenn (6. ábra).

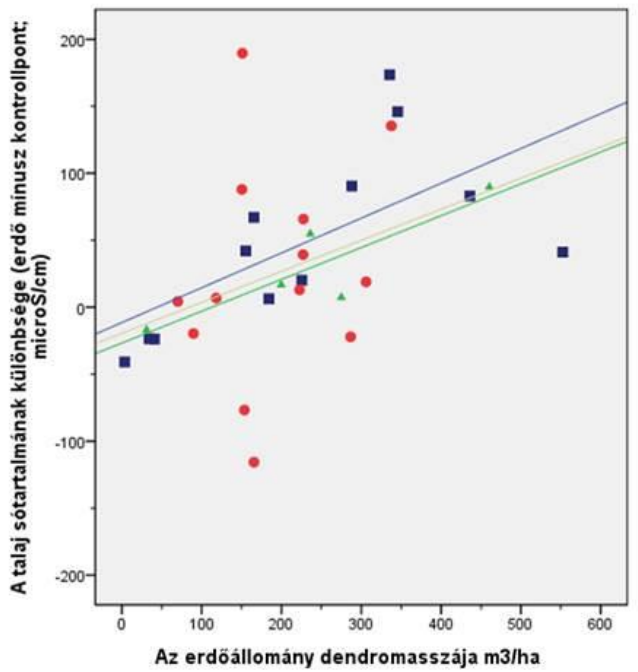

(a)

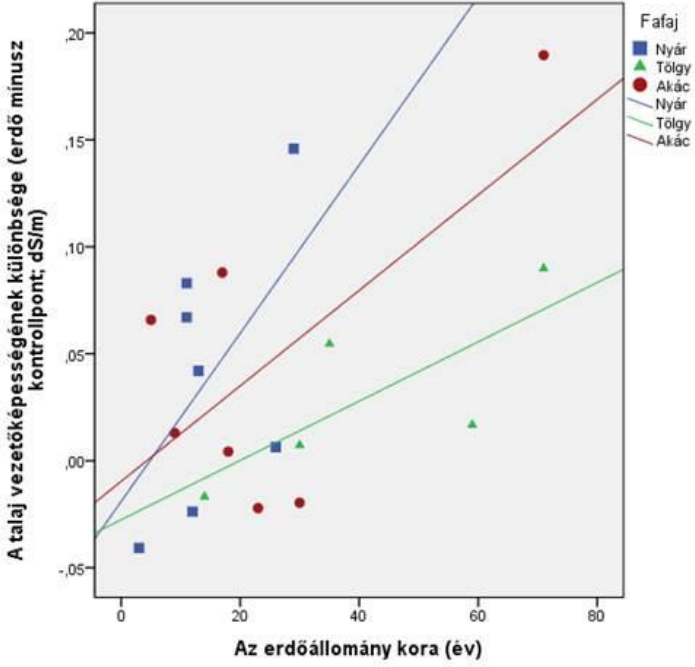

(b)

6. ábra: Összefüggés az erdőállományok dendromasszája (a) kora (b) és az erdő alatt mérhetö sófelhalmozódás (talaj sótartalom, erdő minusz kontrol pont) közt fafajonként (Tóth et al 2014 alapján).

Figure 6: Correlations between forest stand dendromass (a) age (b) and the salt accumulation (soil salinity at forested minus control points) by tree species (based on Tóth et al 2014).

Ez ismételten arra utal, hogy az akác esetében a talajvízzel való kapcsolat általában közvetett, ezért a vízfelvétele által generált iontranszport is korlátozott mértékü.

\section{ÖSSZEFOGLALÁS}

Az eredmények általánosságban alátámasztják az alaphipotézisben feltételezett, továbbá a korábbi szakirodalomban is leírt jelenséget, miszerint az erdőállományok alatt talajvíz depresszió alakul ki, aminek oka az erdőállományok megnövekedett vízfelvételében keresendö. Ugyanakkor miközben a vizsgált fafajok közül - a szakirodalmi adatok és az adatbázisból számítottak alapján is - a nyár vízfelvétele a legnagyobb, az alatta kialakuló talajvíz 
depresszió mértéke nem nagyobb, mint az akác esetében, miközben ez utóbbi gyökérzete általában csak közvetett kapcsolatban áll a talajvízzel.

Ezért nagyon fontos kihangsúlyozni, hogy a (talajvízböl való) vízfelvétel mértéke és a megfigyelhetö talajvizszint süllyedés mértéke közt nem közvetlen az összefüggés. Ez az egyéb, lokális befolyásoló tényezők alapvető fontosságára hívja fel a figyelmet. llyenek a topográfiai, hidrológiai viszonyok, a talajtextúra, illetve az egyes fafajok eltérő vízfelvételi stratégiája.

A fafajok talajvizfelvételének pontosabb meghatározásához tehát nem elegendő egy egyszeri mérés, amely a talajvízszintekben jelentkező különbségeket detektálja, hanem folyamatos több vegetációs időszakon keresztüli talajvízmonitoring alapján vonhatunk le csak komolyabb következtetésket. A nagy gyakoriságú (legalább órás), automaták által is rögzített talajvizállásmérés lehetőséget ad a vegetáció talajvizfelvételének számításához, de sok más a felszín alatti közeget jellemző szivárgáshidraulikai paraméter meghatározásához is.

A fent leírtakat kiegészítő, új információkat adhat továbbá a talajvíz felvétele által generált ionakkumuláció vizsgálata is. Ennek mértéke és mélységi elhelyezkedése a nyár és a tölgy esetében szintén egybevág az alaphipotézisben feltételezettekkel. Az akác esetében az akkumuláció nem kimutatható, illetve csökkent mértékű. Ez azt mutatja, hogy az eltérő talajvízgyökérzet kapcsolatok felderítésére alkalmas eszköz lehet a talajban történő iontranszport vizsgálata.

\section{KÖSZÖNETNYILVÁNÍTÁS}

A publikáció megírását az EFOP 362-16-2017-00018 „Termeljünk együtt a természettel Az agrárerdészet, mint új kitörési lehetőség" pályázat támogatta.

\section{FELHASZNÁLT IRODALOM}

Balog K., Gribovszki Z., Szabó A., Jobbágy E.G., Nosetto M., Kuti L., et al. 2014: Alföldi telepített erdők hatása a felszín alatti sófelhalmozódásra sekély talajvizü területeken. Agrokémia és Talajtan 63: 249-268.

Csáfordi P., Szabó A., Balog K., Gribovszki Z., Bidló A. \& Tóth T. 2017: Factors controlling the daily change of water table during the growing season on the Great Hungarian Plain: a statistical approach. Environmental Earth Sciences 76(20): 675. DOI: 10.1007/s12665-017-7002-1

Göbölös A. 2002: A „vízhiányos” erdőgazdálkodás kérdései a Duna-Tisza közi homokháton. Hidrológiai Közlöny 82(6): 324-326.

Gribovszki Z., Kalicz P., Szilágyi J. \& Kucsara M. 2008: Riparian zone evapotranspiration estimation from diurnal groundwater level fluctuations. Journal of Hydrology 349(1-2): 6-17. DOI: 10.1016/i.jhydrol.2007.10.049 
Gribovszki Z., Kalicz P., Balog K., Szabó A. \& Tóth T. 2014: Comparison of groundwater uptake and salt dynamics of an oak forest and of a pasture on the Hungarian Great Plain. Acta Silvatica et Lignaria Hungarica 10(1): 103-114. DOI: 10.2478/aslh-2014-0008

ljjász E. 1938: Az erdő szerepe a természet vízháztartásában. Hidrológiai Közlöny 18: 416-445.

Járó Z. 1981: A hazai erdők vízfogyasztása. Agrártudományi közlemények 40(2-4): 353-356.

Jobbágy E.G. \& Jackson R.B. 2007: Groundwater and soil chemical changes under phreatophytic tree plantations. Journal of Geophysical Research 112: G02013. DOI: 10.1029/2006JG000246

Keresztesi B. 1968: Morphological characteristics of the Robinia root system on different sites of the Great Hungarian Plain. In: International Symposium Methods of Productivity Studies in Root Systems and Rhizosphere Organisms, Moscow, 28 August - 12 Sept. Nauka, Leningrad, 86-95.

Major P. 2002: Síkvidéki erdők hatása a vízháztartásra. Hidrológiai Közlöny 82(6): 319-324.

Móricz N., Tóth T., Balog K., Szabó A., Rasztovits E. \& Gribovszki Z. 2016: Groundwater uptake of forest and agricultural land covers in regions of recharge and discharge. iForest 9: 696-701. DOI: 10.3832/ifor1864$\underline{009}$

Szabó A., Gribovszki Z., Jobbágy E.G., Balog K., Bidló A. \& Tóth T. 2018: Subsurface accumulation of $\mathrm{CaCO}_{3}$ and $\mathrm{Cl}$ from groundwater under black locust and poplar plantations. Journal of Forestry Research 30: 1353-1361. DOI: 10.1007/s11676-018-0700-z

Szodfridt I. 1993: Az erdő és a talajvizek kapcsolata Duna-Tisza közi hátságon. Hidrológiai Közlöny 73(1): 4445.

Tóth T., Balog K., Szabó A., Pásztor L., Jobbagy E.G., Nosetto M.D. et al. 2014: Influence of lowland forests on subsurface salt accumulation in shallow groundwater areas. AoB Plants 6: plu054. DOI: 10.1093/aobpla/plu054

White W.N. 1932: A method of estimating ground-water supplies based on discharge by plants and evaporation from soil: Results of investigations in Escalante Valley, Utah. (report) US. Geological Survey, Water Supply Paper 659-A: 1-105. DOI: $\underline{10.3133 / \text { wsp659a }}$

Érkezett: 2019. október 3.

Közlésre elfogadva: 2019. november 15. 